\title{
The Poor Law, Migration, and Economic Growth
}

GEORGE R. BOYER

The loss to the English economy caused by decreased migration resulting from relief payments to agricultural laborers is estimated. I conclude that, at worst, the Poor Law had a small negative impact on national product. If poor relief and wages were substitutes, the Poor Law may have had a positive impact on capital formation and economic growth.

$\mathrm{H}$

ISTORIANS have debated the microeconomic impact of the English Poor Law for nearly two centuries. It is now generally agreed that the granting of outdoor relief to able-bodied laborers did not have the disastrous consequences for the rural parish economy that contemporary observers and many historians had claimed. However, revisionist historians have yet to confront a second criticism of the Old Poor Law: that at the macro level outdoor relief caused a reduction in the rate of economic growth by slowing the rate of migration from the agricultural South to London and the industrial Northwest. ${ }^{1}$ Because the marginal product of labor was significantly higher in industrial cities than in agricultural areas, the Poor Law might have caused the early nineteenth-century British economy to forego a large free lunch by fostering an inefficient allocation of labor.

One explanation for the large rural-urban wage gaps that existed during the first half of the nineteenth century was that the payment of outdoor relief to agricultural laborers hindered migration. According to Arthur Redford, "the mistaken and lax administration of poor relief in the southern counties" prior to 1834 was a major cause of "the immobility of the southern agricultural laborer." ${ }^{2}$ Karl Polanyi agreed that the Poor Law slowed rural-urban migration, but his story differed from that of Redford. By the beginning of the nineteenth century, Polanyi argued, "agriculture could not compete with town wages. . . . Methods had to be found which would . . . prevent the draining off of

Journal of Economic History, Vol. XLVI, No. 2 (June 1986). (C) The Economic History Association. All rights reserved. ISSN 0022-0507.

The author is Assistant Professor, Department of Labor Economics, New York State School of Industrial and Labor Relations, Cornell University, Ithaca, New York 14851-0952.

1 would like to thank Claudia Goldin, Peter Lindert, Mary MacKinnon, Joel Mokyr, and Jeffrey Williamson for helpful comments on an earlier version of this paper.

*The idea that the Poor Law "may have had some overall positive effects on the Industrial Revolution" was recently suggested by Joel Mokyr, "The Industrial Revolution and the New Economic History," in Joel Mokyr, ed., The Economics of the Industrial Revolution (New York, 1985), pp. 14-15. The results of this paper support some of Mokyr's hypotheses.

${ }^{2}$ Arthur Redford, Labour Migration in England, 1800-1850 (1st ed., 1926; 2nd ed., New York, 1968), pp. 93-94. 
rural labor, and raise agricultural wages without overburdening the farmer. Such a device was the Speenhamland Law." ${ }^{3}$ Both Redford and Polanyi maintained that relief expenditures raised laborers' annual incomes above the marginal product of labor. Unlike Redford, however, Polanyi did not dismiss the system of outdoor relief as mistaken. Rather, he argued that farmers used outdoor relief to raise their workers' incomes above the marginal product of labor, without increasing their own contributions to the "wages fund."

Neither Redford nor Polanyi offers any evidence that the use of outdoor relief by rural parishes significantly slowed migration to industrial areas. However, an estimate of the Poor Law's impact on labor mobility can be obtained by determining the extent to which relief payments raised agricultural laborers' incomes above the marginal product of labor and comparing this increase with rural-urban wage gaps. Because the results obtained from this procedure depend critically on the assumptions, three models of the economic role of poor relief are presented.

The first model assumes that farmers paid their workers a wage rate equal to the marginal product of labor, so that any relief payments to able-bodied laborers were in excess of their marginal product. Such a policy was clearly inefficient from the point of view of labor-hiring farmers because a farmer's total payment to each worker would exceed the worker's marginal product by an amount Afl, where $B$ is equal to the worker's relief benefits, and A equals the farmer's share of the poor rate. While it is difficult to believe that parishes dominated by labor-hiring farmers would adopt such a relief policy, Redford and others have argued that relief was administered in this manner from 1795 to 1834.

The effect of poor relief on laborers' income can be estimated by calculating the ratio of annual relief benefits per agricultural laborer to annual wage income. Because it is not possible to determine what proportion of a parish's expenditures on poor relief went to agricultural laborers and their families, I calculated the benefit-to-wage income ratio in three ways, assuming that payments to agricultural laborers' families constituted 33 percent, 50 percent, and 67 percent of total relief expenditures. ${ }^{4}$ The results of these calculations are given for several

\footnotetext{
${ }^{3}$ Karl Polanyi, The Great Transformation (New York, 1944), p. 94.

${ }^{4}$ Despite the extensive literature on the Old Poor Law, very little is known about the composition of the "pauper host." The Poor Law acted as "a welfare state in miniature," relieving not only able-bodied laborers but also aged and infirm persons, widows, and orphans. Unfortunately, available data do not enable us to distinguish among types of recipients. Instead of trying to estimate the proportion of relief expenditures going to agricultural laborers' families, I chose three plausible values for it ( 33 percent, 50 percent and 67 percent), and provide three estimates of each result in Tables 1 to 4 . For the counties included in the analysis, the proportion of families chiefly employed in agriculture as of 1831 varied from 0.33 to 0.57 . These data, along with the fact that able-bodied laborers were not the sole recipients of relief, suggest that the actual proportion of relief expenditures going to agricultural laborers and their families was somewhere between 0.33 and 0.5 .
} 
TABLE 1

IMPACT OF POOR RELIEF ON AGRICULTURAL LABORERS' INCOME: MODEL 1

\begin{tabular}{|c|c|c|c|c|c|c|c|}
\hline \multirow[b]{2}{*}{ County } & \multirow{2}{*}{$\begin{array}{l}\text { Expected Annual } \\
\text { Wage Income }\end{array}$} & \multicolumn{3}{|c|}{$\begin{array}{c}\text { Estimated Relief Expen- } \\
\text { ditures Per Agricultural } \\
\text { Laborer }\end{array}$} & \multicolumn{3}{|c|}{$\begin{array}{l}\text { Percentage Increase in Labor- } \\
\text { ers' Income as a Result of } \\
\text { Poor Relief }\end{array}$} \\
\hline & & (1) & (2) & (3) & (1) & (2) & (3) \\
\hline Bedford & $£ 25.50$ & $£ 2.22$ & $£ 3.33$ & $£ 4.44$ & $8.7 \%$ & $13.1 \%$ & $17.4 \%$ \\
\hline Berkshire & 27.30 & 2.73 & 4.09 & 5.46 & 10.0 & 15.0 & 20.0 \\
\hline Buckingham & 26.95 & 2.88 & 4.32 & 5.76 & 10.7 & 16.0 & 21.4 \\
\hline Cambridge & 26.18 & 2.21 & 3.31 & 4.42 & 8.4 & 12.6 & 16.9 \\
\hline Essex & 26.48 & 2.42 & 3.63 & 4.84 & 9.1 & 13.7 & 18.3 \\
\hline Hertford & 28.39 & 2.18 & 3.27 & 4.36 & 7.7 & 11.5 & 15.4 \\
\hline Huntingdon & 29.36 & 2.30 & 3.45 & 4.60 & 7.8 & 11.7 & 15.7 \\
\hline Kent & 32.26 & 3.36 & 5.04 & 6.72 & 10.4 & 15.6 & 20.8 \\
\hline Norfolk & 28.27 & 2.83 & 4.25 & 5.66 & 10.0 & 15.0 & 20.0 \\
\hline Northampton & 24.96 & 2.89 & 4.32 & 5.78 & 11.6 & 17.4 & 23.2 \\
\hline Oxford & 25.03 & 2.85 & 4.27 & 5.70 & 11.4 & 17.1 & 22.8 \\
\hline Southampton & 26.95 & 3.12 & 4.67 & 6.24 & 11.6 & 17.3 & 23.2 \\
\hline Suffolk & 26.00 & 2.82 & 4.23 & 5.64 & 10.8 & 16.3 & 21.7 \\
\hline Sussex & 28.73 & 3.63 & 5.45 & 7.26 & 12.6 & 19.0 & 25.3 \\
\hline Wiltshire & 22.25 & 2.69 & 4.03 & 5.38 & 12.1 & 18.1 & 24.2 \\
\hline
\end{tabular}

Note: Columns 1 through 3 assume that 33 percent, 50 percent and 67 percent, respectively, of relief expenditures were paid to agricultural laborers and their families.

Sources: Wage income data was obtained from George R. Boyer, "The Old Poor Law and the Agricultural Labor Market in Southern England: An Empirical Analysis," this JOURNAL, 46 (Mar. 1986), p. 122. Data on relief expenditures were obtained from House of Commons, Accounts and Papers, vol. 47 (London, 1835).

southeastern counties for the year 1831 in Table 1 . The estimated effect of poor relief on the annual income of agricultural laborers varied significantly across counties. In Sussex, the county with the highest per capita relief expenditures in England in 1831, poor relief raised workers' annual income 12.6 to 25.3 percent above the marginal product of labor, while, at the other end of the scale, laborers in Hertford experienced a 7.7 to 15.4 percent increase in income as a result of the Poor Law.

To judge the impact of poor relief on rural-urban migration, the results in Table 1 must be compared with some measure of rural-urban wage differentials. Because those southern agricultural laborers who did migrate * 'moved overwhelmingly . . . towards London," I focus on wage gaps between London and the rural South. In 1831, builders' laborers in London earned between 21 and 22.5 shillings per week. Assuming a 44-week year, this implies an annual income of $£ 47.5 .^{5}$ The average expected wage income for agricultural laborers in 15 southeastern counties (excluding the home counties of Middlesex and Surrey)

\footnotetext{
${ }^{5}$ Data on the wage rates of London laborers were obtained from Arthur Bowley, Wages in the United Kingdom in the Nineteenth Century (Cambridge, 1900), p. 93. Henry Mayhew estimated that 30 percent of workers in the London building trade were unemployed during slack seasons. Cited in Gareth Stedman Jones, Outcast London (Oxford, 1971), p. 41. If the slack season was six months long, a laborer's expected number of weeks worked per year would be $26+.7(26)$, or 44.2.
} 
was $£ 27.1$ in 1832. Adjusting for regional differences in the cost of living, the unskilled wage differential between London and the South for 1832 is 60.2 percent. $^{6}$ Similar wage gaps existed between the rural South and the industrial Northwest. Manchester builders' laborers earned 17 to 18 shillings per week in 1839, which was 64 percent higher in real terms than the average weekly wage of southern agricultural laborers in $1837 .{ }^{7}$ The calculated wage gap between London and each southeastern county is given in column 1 of Table 2. Columns 2 through 4 contain estimates of the proportion of the wage gap eliminated by the payment of poor relief to able-bodied laborers.

What can be concluded about the impact of poor relief on labor mobility? If the proportion of relief expenditures paid to agricultural laborers was between 0.33 and 0.5 , poor relief eliminated, on average, 16 to 25 percent of the rural-urban wage gap. While these results offer some support for Redford's hypothesis that the payment of poor relief to agricultural laborers hindered migration, large wage gaps remain after accounting for relief expenditures, suggesting that migration to London continued to be an attractive option for rural workers.

The results in Tables 1 and 2 can be used to estimate the loss in national product which the Poor Law caused by slowing rural-urban migration. I begin by estimating the potential gain to national product from eliminating the misallocation of labor between London and the southeastern agricultural counties. Suppose the demand for labor in agriculture and urban unskilled occupations (manufacturing) can be written as:

$$
L_{a}=e^{a a} W{ }^{a}
$$

and

$$
L^{\wedge} \quad \mathrm{C} \quad r f_{m}
$$

where $L$ is the demand for labor, $W$ is the wage rate, $e$ is the exponential function, and $a$ and $\mathrm{m}$ refer to agriculture and urban unskilled occupations. For simplicity, I assume that labor supply equals labor demand at the existing wage in each sector. Given data on $L_{a}, \mathrm{~L}_{\mathrm{m}}, W_{a}$, and $W_{m}$, and estimates of $p_{a}$ and $/ 3_{\mathrm{m}}$ (the own-wage elasticities of demand for labor in agriculture and manufacturing), the equations can be solved for $e^{\prime *}$ and $e^{a m}$. The equilibrium wage rate in the absence of labor misallocation is then obtained by adding the equations together and solving for $\mathrm{W}^{*}$. Substituting $\mathrm{W}^{*}$ into the original labor demand equations, one can

\footnotetext{
${ }^{6}$ Cost of living data was obtained from N.F.R. Crafts, "Regional Price Variations in England in 1843: An Aspect of the Standard-of-Living Debate," Explorations in Economic History, 19 (Jan. 1982), p. 62.

${ }^{7}$ Wage data for Manchester builders' laborers was obtained from Arthur Bowley, "The Statistics of Wages in the United Kingdom during the Last Hundred Years-Wages in the Building Trades," Journal of the Royal Statistical Society, 63 (1900), p. 310. Data on agricultural laborers' wages was obtained from Bowley, Wages in the United Kingdom, table at end of book.
} 
TABLE 2

IMPACT OF POOR RELIEF ON RURAL-URBAN WAGE GAPS

\begin{tabular}{|c|c|c|c|c|c|c|c|c|}
\hline \multirow[b]{2}{*}{ County } & \multirow{2}{*}{$\begin{array}{l}\text { Real Wage Gap } \\
\text { Vis-a-Vis London }\end{array}$} & \multicolumn{3}{|c|}{$\begin{array}{c}\text { Percentage of Wage Gap Eliminated by } \\
\text { Poor Relief }\end{array}$} & \multirow{2}{*}{$\begin{array}{c}\text { Real Wage Gap } \\
\text { (assuming a 20\% } \\
\text { disamenities premium) }\end{array}$} & \multicolumn{3}{|c|}{$\begin{array}{c}\text { Percentage of Wage Gap Eliminated by } \\
\text { Poor Relief }\end{array}$} \\
\hline & & (1) & (2) & (3) & & (1) & (2) & (3) \\
\hline Bedford & $73.6 \%$ & $11.8 \%$ & $17.8 \%$ & $23.6 \%$ & $38.9 \%$ & $22.4 \%$ & $33.7 \%$ & $44.7 \%$ \\
\hline Berkshire & 62.2 & 16.1 & 24.1 & 32.2 & 29.7 & 33.7 & 50.5 & 67.3 \\
\hline Buckingham & 64.3 & 16.6 & 24.9 & 33.3 & 31.4 & 34.1 & 51.0 & 68.2 \\
\hline Cambridge & 64.1 & 13.1 & 19.7 & 26.4 & 31.4 & 26.8 & 40.1 & 53.8 \\
\hline Essex & 62.3 & 14.6 & 22.0 & 29.4 & 29.9 & 30.4 & 45.8 & 61.2 \\
\hline Hertford & 55.9 & 13.8 & 20.6 & 27.5 & 24.7 & 31.2 & 46.6 & 62.3 \\
\hline Huntingdon & 46.4 & 16.8 & 25.2 & 33.8 & 17.1 & 45.6 & 68.4 & 91.8 \\
\hline Kent & 32.8 & 31.7 & 47.6 & 63.4 & 6.3 & 165.1 & 247.6 & 330.2 \\
\hline Norfolk & 52.0 & 18.1 & 26.9 & 38.5 & 21.6 & 46.3 & 69.4 & 92.6 \\
\hline Northampton & 66.8 & 17.4 & 26.0 & 34.7 & 33.6 & 34.5 & 51.8 & 69.0 \\
\hline Oxford & 76.9 & 14.8 & 22.2 & 29.6 & 41.5 & 27.5 & 41.2 & 54.9 \\
\hline Southampton & 59.0 & 19.7 & 29.3 & 39.3 & 27.2 & 42.6 & 63.6 & 85.3 \\
\hline Suffolk & 65.3 & 16.5 & 25.0 & 33.2 & 32.5 & 33.4 & 50.5 & 66.8 \\
\hline Sussex & 49.1 & 25.7 & 38.7 & 51.5 & 19.3 & 65.3 & 98.4 & 131.1 \\
\hline Wiltshire & 97.7 & 12.4 & 18.5 & 24.8 & 58.0 & 20.9 & 31.2 & 41.7 \\
\hline
\end{tabular}

Note: Columns 1 through 3 assume that 33 percent, 50 percent and 67 percent, respectively, of relief expenditures were paid to agricultural laborers and their families.

Sources'. See text and Table 1. 
determine the optimal distribution of labor between the two sectors, $\mathrm{L}_{\mathrm{fl}}{ }^{*}$ and $\mathrm{L}_{\mathrm{m}}{ }^{*}$. It is then a simple process to determine the dead-weight social loss caused by the misallocation of labor between London and the fifteen southeastern counties. Assuming that $f i_{a}=-0.5$ and $\mathrm{j} 8_{\mathrm{m}}=-1.5$, the dead-weight loss was equal to $£ 430,000$ in 1831 , or 0.13 percent of national product. ${ }^{8}$ While this is a small percentage, it represents 5.1 percent of the annual rate of growth of commodity output for 1821 to $1831 .{ }^{9}$

How much of the dead-weight loss resulted from the payment of poor relief to agricultural laborers? If poor relief eliminated 16 to 25 percent of the rural-urban wage gap, one could argue that no more than 25 percent of the dead-weight loss can be attributed to the Poor Law. In other words, the decline in migration caused by poor relief reduced national income by at most $£ 107,500$ in 1831 .

For those who consider the above estimate to be too small, a second method for determining the dead-weight loss is offered. Given estimates of the elasticity of migration with respect to rural income and data on the actual number of migrants out of the southern agricultural counties, the number of migrants in the absence of poor relief can be estimated. Census data for 1851 and 1861 suggest that the income elasticity of migration was between -0.292 and $-0.498 .{ }^{10}$ Combining these estimates with the results in Table 1 indicates that the rate of out-migration from the rural South declined by 3.2 to 10.5 percent as a result of the Poor Law.

Phyllis Deane and W. A. Cole estimate that 515,000 persons migrated out of the southern counties between 1801 and 1831, mostly to London. ${ }^{11}$ To get an upper bound estimate of the impact of poor relief, suppose that 600,000 persons migrated during the period, or 20,000 a year. It follows that the payment of poor relief to rural laborers caused an annual reduction in migration of 661 to 2,346 persons from the rural South. Given an average real wage gap of $£ 16.3$ in 1831, the annual dead-weight loss attributable to poor relief was between $£ 10,774$ and $£ 38,240$. Even if the income elasticity of migration is assumed to be as

\footnotetext{
${ }^{8}$ Data on national product were obtained from Phyllis Deane and W. A. Cole, British Economic Growth 1688-1959 (2nd ed., Cambridge, 1967), p. 166. The loss in national product was also estimated for other values of $\mathrm{ft}$ and $\mathrm{ft}$. Assuming that $\mathrm{ft}=-0.5$ and $\mathrm{ft},=-1.0$, the estimated dead-weight loss was equal to $£ 377,000$. For $\mathrm{ft}=-1.0$ and $\mathrm{ft}=-1.0$, the estimated dead-weight loss equaled $£ 546,000$. Obviously, the choice of own-wage elasticities does not have a large impact on the estimated loss in national product.

${ }^{9}$ Commodity output grew at an annual rate of 2.50 percent from 1821 to 1831 . N.F.R. Crafts, British Economic Growth During the Industrial Revolution (Oxford, 1985), p. 47.

${ }^{10}$ The estimates of the income elasticity of migration were obtained from Richard Vedder and David Cooper, "Nineteenth Century English and Welsh Geographic Labor Mobility: Some Further Evidence," Annals of Regional Science, 8 (June 1974), p. 134; and Michael Greenwood and Lloyd Thomas, "Geographic Labor Mobility in Nineteenth Century England and Wales," Annals of Regional Science, 1 (Dec. 1973), p. 102.
}

${ }^{11}$ Deane and Cole, British Economic Growth, p. 118. 
large as -1.24 (the largest estimate cited in a survey article on migration in developing counties), the best guess estimate of the annual deadweight loss is only $£ 80,700$, or 0.02 percent of national product. ${ }^{12}$

Up to this point I have ignored the issue of urban disamenities. If part of the urban wage represented a "disamenities premium," then the true rural-urban wage gap was smaller than 60.2 percent, and the percentage of the wage gap eliminated by poor relief was correspondingly larger. Suppose that 20 percent of the wage paid to unskilled London laborers was in fact a compensating wage differential necessary to induce workers to live in London. ${ }^{13}$ Column 5 of Table 2 contains estimates of the real wage gap between London and each southeastern county in 1831, and columns 6 to 8 contain estimates of the proportion of the wage gap eliminated by poor relief. If 33 to 50 percent of relief payments went to agricultural laborers, then the Poor Law eliminated from one-third to two-thirds of the wage gap, which must have significantly slowed migration to London. However, with a 20 percent disamenities premium, the dead-weight loss caused by the misallocation of labor in the Southeast was equal to only $£ 105,500$ in 1831 , so that even if the Poor Law was the sole cause of labor's misallocation, its impact on national product was small.

The above results all lead to the same conclusion. Even if all relief payments to agricultural laborers were in excess of their marginal product, there is no evidence that the Poor Law kept the English economy from enjoying a large free lunch associated with transferring workers from low productivity agricultural jobs to high productivity urban employment. Moreover, there are two reasons to believe that the above results significantly overestimate the impact of poor relief on migration and national product. First, I have assumed, for simplicity, that relief expenditures were distributed evenly among agricultural laborers. However, married men with large families received much larger relief payments than single males, and single young adults dominated the flow of migrants to English cities. ${ }^{14}$ The most mobile group of rural laborers was therefore that least affected by poor relief.

Second, the assumption that all relief payments were in excess of

\footnotetext{
${ }^{12}$ The income elasticity of migration estimate was obtained from Michael Todaro, "Internal Migration in Developing Countries: A Survey," in Richard Easterlin, ed., Population and Economic Change in Developing Countries (Chicago, 1980), p. 380. The best-guess estimate assumes that 50 percent of relief expenditures went to agricultural laborers.

${ }^{13}$ Williamson found the urban disamenities premium to be between 7 and 13 percent in the North of England during the 1830s and 1840s. The estimated disamenities premium for intraregional migration in the South was negative. Jeffrey G. Williamson, "Was the Industrial Revolution Worth It? Disamenities and Death in 19th Century British Towns," Explorations in Economic History, 19 (July 1982), p. 232.

${ }^{14}$ Jeffrey G. Williamson, "City Immigration, Selectivity Bias and Human Capital Transfers during the British Industrial Revolution," Harvard Institute of Economic Research, Discussion Paper No. 1171 (July 1985), pp. 8-14.
} 
laborers' marginal product is almost certainly incorrect. In contrast, the second model assumes that labor-hiring farmers dominated local parish politics and administered relief in such a way as to maximize profits. Profit-maximizing farmers would have used poor relief as a substitute for wage payments, since part of the poor rate was paid by taxpayers who did not hire labor. ${ }^{15}$ Thus, it cannot be assumed that farmers offered workers a wage rate equal to the marginal product of labor. Suppose instead that the total compensation package paid by farmers to their employees (consisting of wages and farmers' contribution to relief benefits) was equal to labor's marginal product:

$$
W+X B=M P_{\epsilon}
$$

In other words, the system of outdoor relief enabled farmers to reduce their wage payments by an amount AS, equal to their contribution to the poor rate. Farmers' total expenditure on labor was not affected by the Poor Law, and the difference between laborers' income and their marginal product was determined solely by the contribution of nonlabor-hiring taxpayers to the poor rate. A laborer's annual income is thus:

$$
W+B=M P_{i}+(1-X) B
$$

where $(1-X) B$ is the share of relief benefits paid by non-labor-hiring taxpayers. The percentage increase in workers' income above their marginal product brought about by the Poor Law is given by:

$$
(1-X) B / M P_{f}=(1-X) B /(W+X B)
$$

Notice that this is precisely the solution to the problem of rising urban wage rates suggested by Polanyi; farmers used the Poor Law to raise their laborers' annual incomes without increasing their own payments to labor.

To determine the impact of such a policy on rural-urban migration, the value of $(1-A)$, the proportion of poor relief expenditures paid by local taxpayers other than labor-hiring farmers, must be determined. The contribution of non-labor-hiring taxpayers can be estimated using data on the proportion of poor-rate assessments levied on properties valued at less than £20. Available data from rural Suffolk and Southampton suggest that approximately 15 percent of the poor rate came from such assessments. ${ }^{16}$ Since most assessments of more than

\footnotetext{
${ }^{15}$ George R. Boyer, "An Economic Model of the English Poor Law circa 1780-1834," Explorations in Economic History, 22 (Apr. 1985), pp. 157-58. For evidence that labor-hiring farmers followed such policies, see Anne Digby, Pauper Palaces (London, 1978), pp. 105-106; and George R. Boyer, "The Old Poor Law and the Agricultural Labor Market in Southern England: An Empirical Approach," this JOURNAL, 46 (March 1986), p. 130.

${ }^{16}$ Data on the distribution of poor rate assessments in Suffolk and Southampton was obtained from "Returns Relating to Rating of Tenements in Lancashire, Suffolk, Hampshire, and Gloucestershire," House of Commons, Accounts and Papers, 47 (London, 1849), pp. 618-19.
} 


\section{Poor Law and Migration}

TABLE 3

IMPACT OF POOR RELIEF ON AGRICULTURAL LABORERS' INCOME: MODEL 2

\begin{tabular}{|c|c|c|c|c|c|}
\hline County & $\begin{array}{c}\text { Estimated } \\
\text { Income as } \\
(1)\end{array}$ & $\begin{array}{l}\text { ncrease i } \\
\text { Result o } \\
\text { (2) }\end{array}$ & $\begin{array}{l}\text { aborers' } \\
\text { oor Relief } \\
\text { (3) }\end{array}$ & $\begin{array}{l}\text { Real Wage Gap } \\
\text { Vis-a-Vis London }\end{array}$ & $\begin{array}{l}\text { Percentage of Wage Gap } \\
\text { Eliminated by Po }\end{array}$ \\
\hline Bedford & $1.6 \%$ & $2.4 \%$ & $3.1 \%$ & $57.2 \%$ & $4.2 \%$ \\
\hline Berkshire & 1.9 & 2.7 & 3.4 & 44.8 & 6.0 \\
\hline Buckingham & 2.0 & 2.8 & 3.6 & 45.6 & 6.1 \\
\hline Cambridge & 1.6 & 2.3 & 3.0 & 49.1 & 4.7 \\
\hline Essex & 1.7 & 2.5 & 3.2 & 46.3 & 5.4 \\
\hline Hertford & 1.5 & 2.1 & 2.7 & 42.8 & 4.9 \\
\hline Huntingdon & 1.5 & 2.1 & 2.8 & 33.8 & 6.2 \\
\hline Kent & 1.9 & 2.8 & 3.6 & 18.1 & 15.5 \\
\hline Norfolk & 1.7 & 2.5 & 3.4 & 28.9 & 8.7 \\
\hline Northampton & 2.1 & 3.1 & 3.9 & 46.5 & 6.7 \\
\hline Oxford & 2.1 & 3.0 & 3.9 & 55.6 & 5.4 \\
\hline Southampton & 2.1 & 3.0 & 3.9 & 39.6 & 7.6 \\
\hline Suffolk & 2.0 & 2.9 & 3.7 & 46.3 & 6.3 \\
\hline Sussex & 2.3 & 3.3 & 4.2 & 29.5 & 11.2 \\
\hline Wiltshire & 2.2 & 3.2 & 4.1 & 72.8 & 4.4 \\
\hline
\end{tabular}

${ }^{a}$ The calculations in these columns are based on the assumption that 50 percent of relief expenditures were paid to agricultural laborers.

Note: Columns 1 through 3 assume that 33 percent, 50 percent and 67 percent, respectively, of relief expenditures were paid to agricultural laborers and their families.

Sources: See text and Table 1.

$£ 20$ were levied on labor-hiring farmers, I assume that non-labor-hiring taxpayers paid 20 percent of the poor rate in grain-producing areas. ${ }^{17}$

Table 3 contains estimates of the percentage increase in agricultural laborers' annual incomes caused by the Poor Law, and the percentage of the rural-urban wage gap eliminated by relief payments, for the same counties as before. The conclusion to be reached from the results is clear. Farmers may have attempted to use the Poor Law as a dam to "prevent the draining off of rural labor," as Polanyi contended, but such a policy could not have been successful. Even in generous Sussex, poor relief raised laborers' incomes only 2.3 to 4.2 percent above their marginal product. The impact of the Poor Law on national income was correspondingly small. If the income elasticity of migration was equal to -1.24 , the largest of the estimates, the annual dead-weight loss attributable to poor relief was between $£ 6,600$ and $£ 12,200$. The cumulative

\footnotetext{
${ }^{17}$ A complete assessment for Terling, Essex, in 1801 showed that 11.3 percent of the poor rate came from assessments of less than $£ 20$, and 32.8 percent came from assessments of less than $£ 50$ (Essex Record Office, D/P 299/12/4). To obtain an upper bound estimate of the proportion of the poor rate paid by non-labor-hiring taxpayers, suppose that $£ 50$ of assessed value marked the cutoff between labor-hiring and non-labor-hiring taxpayers. The Terling data then suggest that about one-third of the poor rate was paid by non-labor-hiring taxpayers. However, increasing the value of $(1-A)$ from 0.2 to 0.33 does not have a significant impact on the conclusion regarding the effect of poor relief on migration.
} 
loss to the economy from 1795 to 1834 (the generally accepted boundaries for the predominance of outdoor relief) was at most $£ 500,000$, or 0.15 percent of national product in 1831 .

In sum, if labor-hiring farmers considered wages and poor relief to be substitutes, and available evidence suggests that they did, then the Poor Law had a trivial negative impact on labor mobility and national product. Indeed, a plausible case exists in which politically dominant farmers administered relief in such a way as to cause national product to increase. Suppose migration costs and the urban disamenities premium were large enough to account for the entire rural-urban wage gap, so that the regional labor market was in equilibrium between, say, 1820 and 1834. (This is a special case of the third model, which assumes that, despite the existing rural-urban wage differentials, agricultural laborers did not migrate to urban areas if they received an income of some reservation level, assumed equal to the marginal product of labor. ${ }^{18}$ In this case, politically dominant farmers could have used the system of poor relief to reduce their annual payments to workers below the marginal product of labor. Such a policy would have been especially effective in grain-producing areas, where the demand for labor was highly seasonal. ${ }^{19}$ Farmers who had previously offered workers a year-long labor contract at a wage rate equal to the marginal product of labor could now lay off workers during slack seasons, so long as laborers' annual income from wages and poor relief was equal to their reservation income, $R$. This can be expressed as:

$$
R=W+B=W+\backslash B+(1-\backslash) B
$$

Under this system, farmers' labor costs are equal to:

$$
W+\mathrm{AB}=R-(1-\bigvee) B
$$

Thus, farmers' payments to labor are reduced by an amount $(1-\bigvee) B$ per worker, the contribution of non-labor-hiring taxpayers to the relief fund.

The system of poor relief should have no effect on migration in this model; it replaces laborers' wage income one for one. On the other hand, the transfer of income from taxpayers who did not hire labor to labor-hiring farmers should have a positive impact on economic growth. Non-labor-hiring taxpayers consisted mainly of artisans, shopkeepers, and family farmers, whose incomes were significantly below those of labor-hiring farmers. Ironically, the Poor Law transferred income from low to high income individuals and therefore might have increased savings. The reduction in farmers' labor costs should have increased the

\footnotetext{
${ }^{18}$ Of course, this model would also apply if workers' reservation income was less than the marginal product of labor.

${ }^{19}$ For a further discussion of this model, see Boyer, "An Economic Model of the English Poor Law," pp. 154-61.
} 
TABLE 4

INCOME TRANSFER TO LABOR-HIRING FARMERS OR LANDLORDS: MODEL 3

\begin{tabular}{|c|c|c|c|c|c|c|}
\hline \multirow[b]{2}{*}{ County } & \multicolumn{3}{|c|}{$\begin{array}{l}\text { Estimated Income Transfer } \\
\text { Per Abie-Bodied Laborer }\end{array}$} & \multicolumn{3}{|c|}{$\begin{array}{l}\text { Estimated Total Income Transfer to } \\
\text { Labor-Hiring Farmers or Landlords }\end{array}$} \\
\hline & (1) & (2) & (3) & (1) & (2) & (3) \\
\hline Bedford & $£ 0.44$ & $£ 0.67$ & $£ 0.89$ & $£ 5,099$ & $£ 7,764$ & $£ 10,313$ \\
\hline Berkshire & 0.55 & 0.82 & 1.09 & 8,141 & 12,138 & 16,134 \\
\hline Buckingham & 0.58 & 0.86 & 1.15 & 9,711 & 14,399 & 19,254 \\
\hline Cambridge & 0.44 & 0.66 & 0.88 & 6,907 & 10,361 & 13,814 \\
\hline Essex & 0.48 & 0.73 & 0.97 & 18,352 & 27,911 & 37,087 \\
\hline Hertford & 0.44 & 0.65 & 0.87 & 6,468 & $\mathbf{9 , 5 5 5}$ & 12,789 \\
\hline Huntingdon & 0.46 & 0.69 & 0.92 & 2,745 & 4,117 & 5,490 \\
\hline Kent & 0.67 & 1.01 & 1.34 & 24,196 & 36,474 & 48,391 \\
\hline Norfolk & 0.57 & 0.85 & 1.13 & 21,356 & 31,846 & 42,337 \\
\hline Northampton & 0.58 & 0.87 & 1.16 & 10,310 & 15,464 & 20,619 \\
\hline Oxford & 0.57 & 0.85 & 1.14 & 9,119 & 13,598 & 18,238 \\
\hline Southampton & 0.62 & 0.93 & 1.25 & 15,299 & 22,948 & 30,844 \\
\hline Suffolk & 0.56 & 0.85 & 1.13 & 18,502 & 28,084 & 37,335 \\
\hline Sussex & 0.73 & 1.09 & 1.45 & 19,071 & 28,476 & 37,881 \\
\hline Wiltshire & 0.54 & 0.81 & 1.08 & 13,342 & 20,014 & 26,685 \\
\hline Total & & & & 188,618 & 283,149 & 377,208 \\
\hline
\end{tabular}

Note: Columns 1 through 3 assume that 33 percent, 50 percent and 67 percent, respectively, of relief expenditures were paid to agricultural laborers and their families.

Sources: See text and Table 1.

demand for land, causing rents to increase. Thus much, if not all, of the gain to farmers might have been passed on to (wealthier) landlords. The income transfer should have led to increased capital formation in agriculture or increased investment outside of agriculture.

Three estimates of the size of the income transfer are given in Table 4. To get an idea of the magnitude of the transfer, total fixed capital formation in agriculture for all of Great Britain was $£ 3.4$ million per annum during the years 1830 to $1835 .{ }^{20}$ Assuming that 30 to 40 percent of the capital formation took place in the counties listed in Table 4, the annual transfer of income to labor-hiring farmers or landlords represented between 13.9 and 37.0 percent of fixed capital formation in agriculture in the Southeast of England. ${ }^{21}$ Of course, the actual increase in investment would depend on the difference in savings rates among non-labor-hiring taxpayers, labor-hiring farmers, and landlords. Lack of information on savings behavior makes it impossible to accurately estimate the annual increase in investment brought about by the Poor Law, but I would guess that it was on the order of $£ 75,000$ to $£ 150,000$,

\footnotetext{
${ }^{20}$ Charles Feinstein, "Capital Formation in Great Britain," in Peter Mathias and M. M. Postan, eds., Cambridge Economic History of Europe, (Cambridge, 1978), vol. 8, part 1, p. 75.

${ }^{21}$ In 1831, the 15 southeastern counties included in Table 4 contained about 27 percent of the adult male agricultural laborers in Great Britain. My assumption that $\mathbf{4 0}$ percent of capital formation in agriculture took place in these counties is meant to yield a lower bound estimate for the ratio of the income subsidy received by farmers to the amount of fixed capital formation.
} 
or 5.5 to 14.7 percent of fixed capital formation in agriculture. Thus, the Poor Law might have played a role in funding the agricultural improvements of the first third of the nineteenth century.

Each of the above models has pointed to the same conclusion: the administration of poor relief in the rural South did not significantly hinder labor mobility or economic growth during the early nineteenth century. But perhaps the models were poorly specified and did not offer an acceptable test of the hypothesis. Therefore I offer one last test of the effect of poor relief on rural-urban migration. If passage of the Poor Law Amendment Act stimulated migration to urban areas, a decline in rural-urban wage gaps after 1834 should be observed, other things equal. However, data on movements in real wage rates for London builders' laborers and southern agricultural laborers suggest that wage gaps actually increased until at least 1850 . Real weekly wages for London laborers increased by 39.6 percent from 1831 to 1848 , while weekly wage rates for agricultural laborers increased by only 9.2 percent between 1832 and $1850 .^{22}$ The southern regional labor market did not become more efficient as a result of the abolition of outdoor relief.

\section{CONCLUDING COMMENTS}

The above analysis has reached some surprising conclusions which suggest that the traditional interpretation of the English Poor Law's impact on economic growth needs to be revised. The hypothesis that the existence of poor relief for able-bodied agricultural laborers significantly slowed rural-urban migration (and hence economic growth) is not supported by the evidence. Rather than retard economic growth, the Poor Law at worst had little effect on the economy and at best stimulated growth by increasing the profit rates of labor-hiring farmers or the rental income of landlords.

Unfortunately, lack of data has forced me to make several assumptions concerning the proportion of poor relief going to able-bodied laborers, and the proportion of the poor rate paid by non-labor-hiring taxpayers. Before a more precise estimate of the impact of poor relief on economic growth can be achieved, more must be learned about who received poor relief and who paid the poor rate. To overcome the lack of data, I provide what I think are reasonable upper and lower bound estimates for each result. While the results are approximations, I doubt that further research will change the general direction of the conclusions.

\footnotetext{
${ }^{22}$ Wage data were obtained from Bowley, Wages in the United Kingdom, p. 83 and table at end of book. Cost of living data came from Peter H. Lindert and Jeffrey G. Williamson, "English Workers' Living Standards During the Industrial Revolution: A New Look," Economic History Review, 2nd series, 36 (Jan. 1983), p. 11.
} 